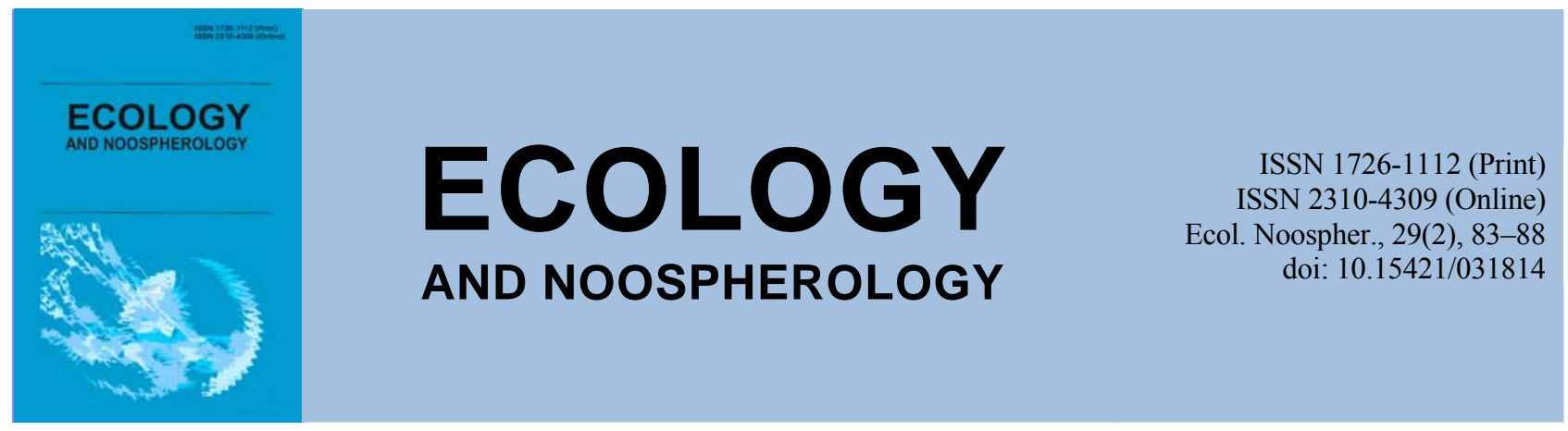

\title{
Diagnostic role of soil physical properties of forest biogeocoenoses of the Ukrainian steppe zone
}

\author{
V. A. Gorban \\ Oles Honchar Dnipro National University, Dnipro, Ukraine
}

Article info

Received 08.10.2018

Received in revised form

15.10.2018

Accepted 20.10.2018

Oles Honchar Dnipro

National University,

Gagarin Ave., 72, Dnipro,

49010, Ukraine.

Tel.: +38-050-362-45-90

E-mail:vad01@ua.fm

\author{
Gorban, V. A. (2018). Diagnostic role of soil physical properties of forest biogeocoenoses of the \\ Ukrainian steppe zone. Ecology and Noospherology, 29(2), 83-88. doi:10.15421/031814
}

For the current stage of the development of soil science it is relevant to search for objectively existing interactions between the various soil properties. Solving this issue most appropriately should be based on the establishment of pedotransfer functions. Pedotransfer functions appeared at the time of the birth of quantitative soil science, when one of the properties of the soil tried to predict others when it became clear that everything in the soil is interrelated when it was established that there is a well-defined number of fundamental, basic properties of the soil, which is basically defines its other properties. Accordingly, the purpose of our work is to establish the diagnostic value of the individual soil physical properties of forest biogeocoenoses of the steppe by means of determining the existing interconnections between them and other properties and characteristics of these soils. The solution of this issue is one of the tasks of developing research on the soil physical properties of forest biogeocoenoses of the Ukrainian steppe zone. The diagnostic value of granulometric and structural-aggregate composition, density and permeability for determining the general state of soils due to the existence of certain interactions between the indicated parameters and other soil properties is considered. The granulometric composition is a fundamental soil characteristic that determines not only the physical state, but also all the main soil properties and regimes of forest biogeocoenoses of the Ukrainian steppe zone. The structural and aggregate composition is an important complex diagnostic feature of chernozem, which helps to reveal the peculiarities of their genesis under the influence of forest vegetation, in particular as a result of changes in the content and composition of organic matter, exchange cations, the influence of root vegetation systems, etc. The soil density, due to existing interactions with other soil properties, is an important diagnostic feature that reflects the features of their genesis and regimes, which determines the specificity of the ecological functions of the soils of forest biogeocoenoses of the Ukrainian steppe zone. Water permeability can be considered as a complex characteristic of soils, which to a certain extent reflects their granulometric composition, porosity, structural and aggregate composition, determines the features of the water-air regime. The differences of physical properties of zonal chernozems and chernozems, the genesis of which are connected with artificial and natural forest biogeocoenoses within the steppe zone of Ukraine, are analyzed. The relevance of the further search for relationships between physical indicators that are easily and promptly analyzed, and other soil properties for expanding diagnostic possibilities with respect to their genesis is pointed out.

Keywords: granulometric composition; structural and aggregate composition; density; water permeability; interconnections; influence of forest vegetation

\section{Діагностичне значення фізичних властивостей грунтів лісових біогеоценозів степової зони України}

\author{
В. А. Горбань
}

\section{Дніпровський національний університет імені Олеся Гончара, Дніпро, Україна}

Розглянуто діагностичне значення гранулометричного та структурно-агрегатного складу, щільності та водопроникності для визначення загального стану грунтів унаслідок існування певних взаємозв'язків між зазначеними показниками та 
іншими грунтовими властивостями. Проаналізовано відмінності фізичних властивостей зональних чорноземів та чорноземних грунтів, генезис яких пов'язаний із штучними та природними лісовими біогеоценозами в межах степової зони України. Зазначено актуальність подальшого пошуку взаємозв'язків між фізичними показниками, які легко та оперативно аналізуються, та іншими властивостями грунтів для розширення діагностичних можливостей відносно їх генезису.

Ключові слова: гранулометричний склад; структурно-агрегатний склад; щільність; водопроникність; взаємозв'язки; вплив лісової рослинності

\section{Вступ}

Для сучасного етапу розвитку грунтознавства актуальним є пошук об'єктивно існуючих взаємозв'язків між різноманітними властивостями грунтів. Вирішення цього питання найбільш доречно повинно базуватися на встановленні педотрансферних функцій. Термін «педотрансферна функція» в наукову літературу вперше ввів Ј. Bouma та Н. А. J. van Lanen (1987), а згодом J. Bouma (1989) використовував цей термін для позначення математичних функціональних залежностей, які дозволяють перетворювати інформацію про основні грунтові (педо-) властивості в інформацію про характеристики переносу (трансфер) вологи в грунті (Shein, Arkhangelskaya, 2006), тобто ці функції забезпечують «переведення даних, які ми маємо, в ті, які нам потрібні» (Medvedev, Laktionova, 2011).

Як зазначають Є. В. Шеїн та Т. О. Архангельська (Shein, Arkhangelskaya, 2006), педотрансферні функції з'явилися в часи зародження кількісного грунтознавства, коли за одними властивостями грунту намагалися передбачити інші, коли стало зрозуміло, що все в грунті взаємопов'язано, коли було встановлено, що $є$ цілком визначений ряд фундаментальних, базових властивостей грунту, який в основному визначає його інші властивості.

Виходячи 3 цього, метою нашої роботи $є$ встановлення діагностичного значення окремих фізичних властивостей грунтів лісових біогеоценозів степу за допомогою визначення існуючих взаємозв'язків між ними та іншими властивостями i характеристиками зазначених грунтів. Вирішення цього питання $\epsilon$ одним із завдань розвитку досліджень фізичних властивостей грунтів лісових біогеоценозів степової зони України (Gorban, 2016).

Гранулометричний склад - це відносний вміст у грунті елементарних грунтових часток різноманітного діаметру, незалежно від їх мінералогічного та хімічного складу (Shein, 2009). Гранулометричний склад виражається передусім у вигляді масових відсотків фракцій гранулометричних часток різноманітного розміру (Teorii .., 2007). Гранулометричний склад $\epsilon$ однією 3 фундаментальних характеристик будь-якого грунту. Відповідно до сучасної концепції ієрархії рівнів структурної організації грунтів (Rozanov, 1975; Voronin, 1986) гранулометричний склад відповідає рівню елементарних грунтових часток, успадкованих від материнської породи та змінених у процесі грунтоутворення. Гранулометричний склад $\epsilon$ доволі сталою характеристикою грунтів, а його зміни у грунтових горизонтах пов'язані 3 проявом процесів лесиважу, опідзолення, оглинення, метаморфозу (Karpachevsky, 2005).

В. В. Медведев та Т. М. Лактіонова (Medvedev, Laktionova, 2011) зазначають, що гранулометричний склад характеризує одну з найважливіших властивостей грунтів ix полідисперсність. Співвідношення в грунтах елементарних часток різноманітних розмірів формує основні властивості та функції грунтів - продуктивні та екологічні. Інакше кажучи, здатність грунтів трансформувати речовини та енергію, взаємодіяти з водою, повітрям, речовинами, що потрапляють до грунту, 3 коренями рослин і в цілому, формування та функціонування грунту як природного компоненту в значній мірі залежить від його гранулометричного складу (Medvedev, Laktionova, 2011).
Л. О. Карпачевський (Karpachevsky, 2005) підкреслює, що багато властивостей грунтів функціонально пов'язані 3 ïх гранулометричним складом. Однак ця пряма функціональна залежність порушується тим, що різні грунти відрізняються за мінеральним складом, а для різних мінералів функціональний зв'язок між розміром їх зерен та властивостями різний. Функціональна залежність також змінюється залежно від вмісту в грунті гумусу. Деякі властивості грунтів разом з гранулометричним складом визначаються гумусом, тому вибір властивостей грунтів, які можуть коригувати дані про гранулометричний склад, $\epsilon$ дуже актуальним завданням. Гранулометричний склад визначає багато інших властивостей грунту, як фізичних, так i хімічних. Упаковка часток створює пористість грунтів, питома поверхня залежить від кількості мулистих часток, а сама питома поверхня грунтів визначає взаємодію коренів рослин та грунту, вилучення поживних речовин 3 грунту, вміст доступної рослинам води та ін. Саме питома поверхня грунтів привертає зараз увагу дослідників як показник їх гранулометричного складу. Гранулометричний склад в тій чи іншій мірі впливає на такі грунтові властивості: щільність, вологоємність, коефіцієнт фільтрації, пористість, максимальна гігроскопічність, вологість в'янення, найменша вологоємність. Отже, гранулометричний склад грунтів - одна 3 основних властивостей, яка визначає багато інших властивостей. Він відповідає за такі екологічні функції грунту, як розповсюдження рослин, забезпечення рослин водою та поживними елементами (Karpachevsky, 2005).

О. Л. Бельгард (Belgard, 1960) вважав гранулометричний (механічний) склад грунтів однією 3 найважливіших характеристик лісорослинних умов, який здійснює вирішальний вплив на фізичні властивості грунтів та хімічні процеси, що в них відбуваються. Перехід від грунтів легкого до грунтів більш важкого гранулометричного складу зумовлюе зростання їх родючості (Belgard, 1971).

Гранулометричний склад виступає базовою характеристикою, часто разом із структурним складом та щільністю, для побудови педотрансферних функцій. Як зазначають В. В. Медведєв та Т. М. Лактіонова (Medvedev, Laktionova, 2011), гранулометричний склад враховується при моделюванні таких педотрансферних функцій: агрегація; деагрегація; грунтово-гідрологічні властивості; фізичні, фізико-механічні та технологічні властивості; міграція вологи та тепла; гумусово-акумулятивна здатність; запас та доступність поживних речовин; біологічна активність. К. І. Лукьященко та Т. О. Архангельська (Lukyashchenko, Arkhangelskaya, 2018) відзначають, що врахування гранулометричного складу дозволяє значно підвищити достовірність та точність моделювання температуропровідності грунтів.

Дослідження гранулометричного складу чорноземів під лісовими насадженнями в умовах степу показало відсутність суттєвого переміщення часток (Stadnichenko, 1960). Разом $з$ тим детальні дослідження степових грунтів під штучними та природними лісами, виконані Н. А. Біловою та А. П. Травлєєвим (Belova, Travleyev, 1999), свідчать про певну диференціацію грунтового профілю на елювіальні та ілювіальні горизонти внаслідок прояву лесиважу, в результаті якого спостерігається міграція мулистих часток 3 верхніх горизонтів до нижніх. При цьому зазначається, що під штучними лісонасадженнями виявлено лише зачаткові ознаки цього процесу, а найбільш чіткі його 
ознаки пов'язані 3 грунтами природних лісів степу, які характеризуються рядом особливостей, відмінних від зональних чорноземів (Travleyev, 1972, 1977; Belova, Travleyev, 1999 та ін.). У першу чергу це позначається на водному режимі, оскільки від гранулометричного складу у значній мірі залежать величини грунтово-гідрологічних констант - гігроскопічної та максимальної гігроскопічної вологи, максимальної молекулярної вологоємності (Kachinsky, 1970). Суттєві коливання гранулометричного складу грунтів зумовлюють зміни типу лісорослинних умов (Gorban, 2009), що може відбиватися на загальному стані лісового біогеоценозу.

Таким чином, гранулометричний склад $\epsilon$ фундаментальною грунтовою характеристикою, яка визначає не лише фізичний стан, а й усі основні властивості та режими грунтів лісових біогеоценозів степової зони України.

Структурно-агрегатний склад - це певний внутрішньогоризонтний рівень організації грунтового тіла, що відображає особливості грунтоутворення певної місцевості, який можна охарактеризувати розміром, формою, щільністю укладання структурних одиниць, зовнішніми та внутрішніми властивостями, а також специфічною динамікою, що також відображає коливання факторів агрегації та деагрегації (Voronin, 1986; Medvedev, 2008).

П. Є. Соловйов (Solovyov, 1967) зазначає, що структура грунту знаходиться в тісній залежності від гранулометричного складу. Під впливом деревної рослинності структура грунту з грудкувато-пилуватої у відкритому степу перетворюється під лісом в грудкуватозернисту та навіть зернисту. Тонкі корені деревних рослин, пронизуючи грунт у всіх напрямах, сприяє цим утворенню агрегатних окремостей. Таким чином, коренева система $\epsilon$ одним 3 факторів утворення структури грунту та підвищення іiі водоміцності. Органічна речовина, що утворюється при розкладанні деревних рослин, посилює цементацію агрегатів та робить їх більш міцними. Водоміцність структурних агрегатів у грунтах під широколистяним лісом значно вища, ніж у грунтах відкритого степу. Кількість водоміцних агрегатів у них у верхніх горизонтах коливається в межах від 50 до 96 \%, у той час як у грунтах відкритого поля таких агрегатів не більше $20 \%$. Найкращою структурою та найбільшою ii водоміцністю характеризуються грунти під лісом. Їх структура знаходиться в тісній залежності від підвищеного вмісту в них перегнійних речовин та насиченості їх поглинутими катіонами - кальцієм та магнієм. Одночасно 3 цим інтенсивні мікробіологічні процеси, які відбуваються в грунтах під лісом, також сприяють формуванню доброї, стійкої проти розмивання водою, структури грунту. Структурність грунту та водоміцність його агрегатів зумовлюються співвідношенням фракцій гранулометричного та структурного аналізу (Solovyov, 1967).

Результати досліджень А. Г. Линді (Lyndya, 1973) свідчать, що під природним байрачним лісом кількість водоміцних агрегатів вища, ніж під степовою рослинністю. Зокрема, у верхньому горизонті зональних чорноземів міститься 66 \% водоміцних агрегатів, а в грунтах липовоясеневої діброви цей показник дорівнює 82 \%. Збільшення водоміцності агрегатів верхнього гумусового горизонту зумовлене впливом деревно-чагарникової рослинності на грунти байрачних лісів (Lyndya, 1973).

П. Г. Адерихін та ін. (Aderikhin et al., 1983) відзначають, що під впливом смугових лісових насаджень в умовах степу грунти відрізняються високою агрегованістю, водоміцністю структурних агрегатів у верхній частині профілю. Коефіцієнт водоміцності становить $0,63-0,87$ для агрегатів розміром понад 1,0 мм та 0,82-0,91 - для агрегатів понад 0,25 мм. Чорноземи лісових смуг за структурністю перевершують перелогові чорноземи. При наближенні до лісової смуги в орному горизонті чорноземного грунту збільшується грудкуватість (від 18-28 до 44-46 \%) та водоміцність агрегатів (Aderikhin et al., 1983).

Дослідження Н. А. Білової (Belova, 1997) свідчать, що лісова рослинність у степу сприятливо впливає на зональні грунти, які покращують свої фізичні властивості, агрегованість, збільшують пористість. Установлено, що більшість лісових рослин порівняно зі степовими характеризуються в 2,0-2,5 разу більшою здатністю до структуроутворення. Коефіцієнт структурності лісових рослин досягає показника 6,4 на відміну від 2,4 на степовій цілині (Belova, 1997).

У результаті досліджень впливу насаджень різних типів світлової структури на зональні чорноземи I. А. Іванько (Ivanko, 2016) було встановлено, що найбільшу агрегованість грунтової маси зі стійкими показниками коефіцієнта структурності за профілем i високими значеннями водоміцності структурних грунтових агрегатів виявлено для насаджень тіньового і напівтіньового типів світлової структури, при більш високих значеннях - у насадженні дуба звичайного. Відзначено, що порівняно зі степовими грунтами в насадженнях тіньового i напівтіньового типів найбільше зростає водотривкість тонких фракцій структурних агрегатів (1-0,5 і 0,5-0,25 мм). Разом 3 тим порівняно 3 контрольними ділянками степових цілинних грунтів у верхньому біогенному грунтовому горизонті (0-10 см) у тіньових насадженнях вміст гумусу зростає в середньому на $0,8 \%$, у напівтіньових - на $0,4 \%$, у полезахисних насадженнях напівосвітленого i освітленого типів - на 0,2-0,3\% (Ivanko, 2016).

Таким чином, структурно-агрегатний склад є важливою комплексною діагностичною ознакою чорноземів, яка допомагає розкрити особливості їх генезису під впливом лісової рослинності, зокрема внаслідок змін у вмісті та складі органічних речовин, обмінних катіонів, впливу кореневих систем рослинності та ін.

Щільність - це маса абсолютно сухого грунту в одиниці об'єму грунту зі всіма властивими природному грунту порожнинами (Teorii .., 2007).

О. Ф. Вадюніна та 3. О. Корчагіна (Vadyunina, Korchagina, 1986) відзначають, що щільність є однією 3 найважливіших фізичних характеристик, що позначається на водному, повітряному, тепловому режимах грунтів. Знати щільність грунту непорушеного складання необхідно для вирішення цілого ряду практичних завдань: обчислення пористості, обчислення на визначеній площі маси грунтових нашарувань, запасів води, поживних речовин, гумусу, мікроелементів, норм поливу при зрошенні та ін. За щільністю складення верхніх горизонтів складають уявлення про окультуреність грунтів. Сильно ущільнений в сухому стані грунт має великий опір розвитку кореневої системи рослин. У перезволоженому щільному грунті створюються несприятливі умови для рослин внаслідок зайнятості майже всього об'єму пор водою і нестачі пор аерації. Щільний грунт погано або зовсім не фільтрує воду. Вода, що надходить на поверхню грунту, не проникає всередину, а стікає, викликаючи процеси ерозії. Щільність сухого грунту непорушеного складання залежить від гранулометричного складу, структури, ïi водної та механічної міцності, пористості, вологості. Вона змінюється в просторі i в часі, особливо у верхніх горизонтах, що піддаються постійному впливу кліматичних, біологічних i антропогенних факторів (Vadyunina, Korchagina, 1986).

А. Д. Воронін (Voronin, 1986) зазначає, що щільність складання сухого грунту в грунтових горизонтах або шарах залежить від гранулометричного складу й агрегованості грунтів, від щільності складення агрегатів і характеру їх упаковки. Це дуже динамічна і в той же час інформативна величина, оскільки дає уявлення про співвідношення твердої частини i порожнин у грунті. Тому іiі широко використовують як при грунтово-генетичних дослідженнях, так i для агротехнічної i грунтово- 
меліоративної оцінки грунтів. У цілому щільність складання сухого грунту вниз за профілем зростає. Це пов'язано з тиском верхньої товщі грунту на нижні шари. Однак іноді ця тенденція порушується появою шарів 3 підвищеною або зниженою щільністю, що може бути наслідком особливостей як грунтотвірного процесу (ілювіальний та елювіальний горизонти), так і вихідної неоднорідності грунтотвірної породи (Voronin, 1986).

Дослідженнями I. I. Назаренка та ін. (Nazarenko et al., 2000) встановлено, що залежність рівноважної щільності верхніх горизонтів основних грунтів України від фізикохімічних факторів $\epsilon$ зворотною. Ступінь тісноти кореляції високий для вмісту обмінного кальцію, гумусу, суми обмінних основ, помітний для вмісту обмінного магнію та ступеня насиченості основами (Nazarenko et al., 2000).

В. В. Медведєв та ін. (Medvedev et al., 2004) відмічають, що щільність складення доволі часто використовується при створенні педотрансферних моделей. Зокрема, виявлено зв'язок між рівноважною щільністю та вмістом гумусу (коефіцієнт кореляції дорівнює -0,64). Установлено існування зв'язку між щільністю та вмістом фізичної глини, найменшою вологоємністю, а також 3 особливостями водно-повітряного режиму (вбиранням, фільтрацією, аерацією та ін.). Зазначається, що отримані педотрансферні моделі $\epsilon$ важливим інструментом, за допомогою якого можна пояснити та формалізувати деякі аспекти генезису щільності складення та її впливу на інші властивості та режими (Medvedev et al., 2004).

За даними I. Є. Олега (Oleg, 1996), щільність верхніх горизонтів грунтів байрачних лісів лежить у межах $1,1-$

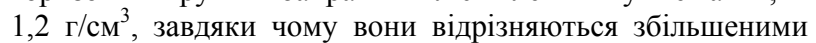
величинами загальної пористості та пор аерації. Н. А. Білова (Belova, 1997) відзначає, що верхні горизонти грунтів під природними байрачними лісами, внаслідок своєї високої агрегованості, відрізняються дуже незначною щільністю, що забезпечує можливість цих грунтів до вбирання величезної кількості вологи.

Таким чином, щільність грунтів, внаслідок існуючих взаємозв'язків 3 іншими грунтовими властивостями, $€$ важливою діагностичною ознакою, яка відображає особливості їх генезису та режимів, зумовлює специфічність прояву екологічних функцій грунтів лісових біогеоценозів степової зони України.

Водопроникність - це процес надходження води в грунт при певному напорі, який включає стадію вбирання (інфільтрації) - проникнення води в не насичений вологою грунт, та наступну стадію фільтрації - пересування води в насиченому вологою грунті (Teorii .., 2007).

Інтенсивність i характер водопроникності грунту залежать від його гранулометричного та механічного складу, від структурності, щільності складення, пористості, вологості грунту та тривалості їх зволоження (Kachinsky, 1970; Nazarov, 1970). На величину і характер водопроникності у великій мірі впливає пористість грунту, а саме величина, форма і спрямованість пір, що, у свою чергу, пов'язано 3 гранулометричним складом i структурністю. У грунтах легкого гранулометричного складу (піщаних, супіщаних), а також безструктурних водопроникність залежить лише від складання гранулометричних елементів; у грунтах структурних вона обумовлена розмірами агрегатів, їх розміщенням відносно один одного i головним чином - водоміцністю. Водопроникність зменшується 3 часом, оскільки при насиченні грунту водою відбувається руйнування структури, поступове ущільнення за рахунок замулювання порового простору (Vadyunina, Korchagina, 1986). Водопроникність залежить від хімічного складу і особливо від водорозчинних сполук, здатних або нездатних коагулювати грунтові колоїди (Rode, Smirnov, 1972).

Показник водопроникності значно залежить від воднофізичних властивостей грунтів i впливає на їхній гідрологічний режим. Опади під впливом сили тяжіння всмоктуються та просочуються по порах 1 тріщинах. У процесі всмоктування частина води заповнює різні пори, інша частина фільтрується у глибинні горизонти, ще інша випаровується 3 поверхні, а також стікає по схилах, утворюючи поверхневий стік. Отже, чим менша водопоглинальна здатність грунтів, тим більше води залишається на їхній поверхні і, відповідно, тим сильніша ерозія. Надходження ж меншої кількості води у грунт супроводжується зниженням продуктивності як окремих популяцій, так і біогеоценозів загалом. Погіршення воднофізичних характеристик грунту призводить до деградації лісового біогеоценозу, що виявляється в посиленні в ньому ерозійних процесів, унаслідок чого простежується змивання підстилки та гумусового шару грунту. Це впливає на здатність лісу до поновлення, посилює процеси деградації, що призводить до незворотних змін у лісових біогеоценозах (Shcherbina, 2002).

Водопроникність - одна з головних рис характеристики грунту. Вона зумовлює життєдіяльність біоти та визначає водний баланс того чи іншого грунту. Від водопроникності залежить інтенсивність поверхневого стоку, а відповідно, і режим зволоження грунту, що має важливе значення в пізнанні життя лісу та під час розробки заходів щодо підвищення продуктивності лісових насаджень. Водопроникність, забезпечуючи сприятливий водноповітряний режим у грунті, $є$ одним із найсуттєвіших чинників його родючості (Gorban, 2007).

Для чорноземів виявлена чітка залежність водопроникності від гранулометричного складу. Найменші показники при цьому характерні для чорноземів легкого гранулометричного складу, з підвищенням у складі грунту часток фізичної глини вбирання та фільтрація збільшуються, а разом з ними покращується міцність структури, що відображається на коефіцієнті загасання водопроникності (Medvedev et al., 2011).

А. П. Травлєєв та ін. (Travleyev et al., 1991) відзначають, що інфільтрація в зональних чорноземах звичайних характеризується відносно помірними показниками. У той же час водопроникність у лісосмузі 3 дуба звичайного майже в 10 разів вища порівняно 3 цілинним степом, що зумовлено кращою агрегованістю лісових грунтів (Belova, 1997).

Таким чином, водопроникність можна розглядати як комплексну характеристику грунтів, яка в певній мірі відображає їх гранулометричний склад, пористість, структурно-агрегатний склад, зумовлює особливості водно-повітряного режиму.

\section{Висновки}

У роботі розглянуто деякі показники фізичного стану грунтів (гранулометричний склад, структурно-агрегатний склад, щільність та водопроникність), які можуть використовуватися для комплексної діагностики загального стану грунтів. Детально наведено характеристику існуючих взаємозв'язків між зазначеними показниками та іншими властивостями грунтів лісових біогеоценозів степової зони України. У подальшому необхідно активізувати роботи щодо виявлення та встановлення особливостей взаємозв'язків між показниками, які легко та оперативно діагностуються (наприклад, електрофізичні показники), та іншими грунтовими властивостями.

\section{References}

Aderikhin, P. G., Belgard, A. L., Zonn, S. V., Krupenikov, I. A., \& Travelyev, A. P. (1983). Vliyaniye lesnoy rastitelnosti na chernozemy [Influence of forest vegetation on chernozems]. Russian black earth -100 years after Dokuchaev. Moscow, 117-126 (in Russian).

Belgard, A. L. (1960). Vvedenie v tipologiyu iskusstvennykh lesov stepnoj zony [Introduction to the typology of 
artificial steppe zone forests]. Artificial forests of steppe zone of Ukraine. Kharkov state university, Kharkov (in Russian).

Belgard, A. L. (1971). Stepnoe lesovedenie [Steppe forestry]. Forestry industry, Moscow (in Russian).

Belova, N. A. (1997). Ekologiya, mikromorfologiya, antropogenez lesnykh pochv stepnoj zony Ukrainy [Ecology, micromorfology, antropogenesis of forest soils in the Steppe zone of Ukraine]. Dnepropetrovsk University Press, Dnepropetrovsk (in Russian).

Belova, N. A., Travleyev, A. P. (1999). Estestvennye lesa i stepnye pochvy (ecologiia, mikromorfologiia, genesis) [Forest and steppe soils (ecology, micromorphology, genesis)]. Dnepropetrovsk (in Russian).

Bouma, J. (1989). Using soil survey data for quantitative land evaluation. Adv. Soil Sci., 9, 177-213.

Bouma, J., van Lanen, H. A. J. (1987). Transfer functions and threshold values: from soil characteristics to land qualities. Proc. of the Int. Workshop on Quantified Land Evaluation Procedures, Washington, DC, USA. 106-110.

Gorban, V. A. (2016). Fizychni vlastyvosti gruntiv ta pidstylok lisovykh bioheotsenoziv stepovoyi zony Ukrayiny [Physical properties of soils and litter forest biogeocoenoses of the steppe zone of Ukraine]. Bioheotsenolohichni doslidzhennya lisiv stepovoyi zony Ukrayiny. Svidler A. L., Dnipro. 142-154 (in Ukrainian).

Gorban, V. A. (2009). Vplyv eolovo-gruntovykh vidkladiv na komponenty ta strukturni elementy lisovykh kulturbioheotsenoziv stepovoyi zony Ukrayiny [Influence of the eolian sediments on the components and structural elements of the artificial forest ecosystems in the Ukrainian steppe areas]. Gruntoznavstvo, 10(1-2), 90-94 (in Ukrainian).

Gorban, V. A. (2007). Zviazok vodopronyknosti gruntiv z inshymy ikhnimy fizychnymy vlastyvostiamy u lisovykh ugrupovanniakh Prysamaria [The relation of soils water infiltration with other physical properties of Prisamarja region wood edaphotopes]. Visnyk of L'viv univ. Biology series, 43, 161-165 (in Ukrainian).

Ivanko, I. A. (2016). Ekolohichna rol svitlovoyi struktury u formuvanni shtuchnykh lisovykh nasadzhen u stepoviy zoni Ukrayiny [Ecological role of light structure in the formation of artificial forest plantations in the steppe zone of Ukraine]. Bioheotsenolohichni doslidzhennya lisiv stepovoyi zony Ukrayiny. Svidler A. L., Dnipro. 155-171 (in Ukrainian).

Kachinsky, N. A. (1970). Fizika pochvy [Soil Physics]. Moscow (in Russian).

Karpachevsky, L. O. (2005). Ekologicheskoe pochvovedenie [Ecological soil science]. GEOS, Moscow (in Russian).

Lukyashchenko, K. I., Arkhangelskaya, T. A. (2018). Modelirovaniye temperaturoprovodnosti pochv razlichnogo granulometricheskogo sostava [Modeling the thermal diffusivity of soils of different grain size distribution]. Eurasian Soil Science, 2, 179-186 (in Russian).

Lyndya, A. G. (1973). O polozhitelnom vliyanii lesnoy rastitelnosti na nekotoryye fizicheskiye svoystva pochv [On the positive influence of forest vegetation on some physical properties of soils ]. DSU, Dnepropetrovsk. Voprosy stepnogo lesovedeniya, 4, 30-33 (in Russian).

Medvedev, V. V. (2008). Struktura pochvy (metody, genesis, klassifikatsiya, evolyutsiya, geografiya, monitoring, okhrana) [Soil structure (methods, genesis, classification, evolution, geography, monitoring, protection)]. Publishing House «13 Press», Kharkiv (in Russian).

Medvedev, V. V., Laktionova, T. N. (2011). Granulometricheskij sostav pochv Ukrainy (geneticheskij, ekologicheskij i agronomicheskij aspekty) [Texture of Ukrainian Soils (genetic, environmental and agronomical aspects)]. Apostrof, Kharkiv (in Russian).
Medvedev, V. V., Laktionova, T. N., Dontsova, L. N. (2011). Vodnye svojstva pochv Ukrainy i vlagoobespechennost selskokhozyajstvennykh kultur [Soil water properties of Ukraine and agricultural crops water supply]. Apostrof, Kharkiv (in Russian).

Medvedev, V. V., Lyndina, T. E., Laktionova, T. N. (2004). Plotnost slodzeniya pochv (geneticheskiy, ekologicheskiy i agronomicheskiy aspekty) [Soils bulk density (genetic, ecological and agronomical aspects)]. 13th Printing House, Kharkiv (in Russian).

Nazarenko, I. I., Berbets, N. A., Cherpinka, V. R. (2000). Ravnovesnaia plotnost i pogloshchayushchiy kompleks osnovnykh pochv Ukrainy [Equilibrium bulk density and adsorption complex of main soils in Ukraine]. Eurasian Soil Science, 10, 1238-1241 (in Russian).

Nazarov, G. V. (1970). Zonalnyye osobennosti vodopronitsayemosti pochv SSSR [Zonal features of the permeability of the soil of the USSR]. Leningrad (in Russian).

Oleg, I. E. (1996). Ekologicheskaia rol fizicheskikh svojstv lesnykh pochv stepnogo Pridneprovia [Ecological role of physical properties of forest soils of the steppe Dnieper]. Thesis for the degree of candidate of biological sciences (03.00.16 - Ecology). Dnipropetrovsk (in Russian).

Rode, A. A., Smirnov, V. N. (1972). Pochvovedeniye [Soil Science]. Moscow (in Russian).

Rozanov, B. G. (1975). Geneticheskaya morfologiya pochv [Genetic soil morphology]. Moscow (in Russian).

Shcherbina, Yu. G. (2002). Vliyaniye fizicheskikh kharakteristik pochvy i polnoty drevostoya na sostoyaniye lesnykh biogeotsenozov Chernomorskogo poberezhya Kavkaza [The influence of the physical characteristics of the soil and the completeness of the stand on the state of the forest biogeocenoses of the Black Sea coast of the Caucasus]. Gruntoznavstvo, 3(3-4), 21-26 (in Russian).

Shein, E. V. (2009). Granulometricheskiy sostav pochv: problemy metodov issledovaniya, interpretatsii rezul'tatov i klassifikatsiy [Soil granulometric composition: problems of research methods, interpretation of results and classifications]. Eurasian Soil Science, 3, 309-317 (in Russian).

Shein, E. V., Arkhangelskaya, T. A. (2006). Pedotransfernyye funktsii: sostoyaniye, problemy, perspektivy [Pedotransfer functions: state of the art, problems, and outlooks]. Eurasian Soil Science, 10, 1205-1217 (in Russian).

Solovyov, P. Ye. (1967). Vliyaniye lesnykh nasazhdeniy na pochvoobrazovatelnyy protsess i plodorodiye stepnikh pochv [The influence of forest plantations on the soilforming process and the fertility of steppe soils]. Moscow (in Russian).

Stadnichenko, V. G. (1960). Pochvy iskusstvennykh lesov stepnoy zony USSR [Soils of artificial forests of the steppe zone of the Ukrainian SSR]. Iskusstvennyye lesa stepnoy zony Ukrainy. Kharkov, 75-84 (in Russian).

Teorii i metody fiziki pochv (2007) [Theories and techniques of soil physics]. Ed. E. V. Shein, L. O. Karpachevskij. Moscow (in Russian).

Travleyev, A. P. (1972). Materialy k nomenklature i klassifikatsii lesnykh pochv podzony nastoyashchikh stepey [Materials to the nomenclature and classification of forest soils of the subzone of these steppes]. DSU, Dnepropetrovsk. Voprosy stepnogo lesovedeniya, 3, 16-21 (in Russian).

Travleyev, A. P. (1977). Kharakteristika pochv lesnykh kul'turbiogeotsenozov nastoyashchikh stepey USSR [Characteristics of the soil of forest cultures and biogeocenoses of real steppes of the Ukrainian SSR]. Voprosy stepnogo lesovedeniya i okhrany prirody. DSU, Dnepropetrovsk. 8-21 (in Russian).

Travleyev, A. P., Belova, N. A., Travleyev, L. P. (1991). Vodnyye i mikromorfologicheskiye svoystva pochv stepnikh biogeotsenozov Prisamarskogo monitoringa 
[Water and micromorphological properties of the soils of the steppe biogeocenoses of the Prisamarie monitoring]. Kadastrovyye issledovaniya stepnikh BGTS Prisamar'ya Dneprovskogo, ikh antropogennaya dinamika i okhrana. DSU, Dnepropetrovsk. 4-20 (in Russian).
Vadyunina, A. F., Korchagina, Z. A. (1986). Metody issledovaniia fizicheskikh svojstv pochvy [Methods of study of the physical properties of soil]. Moscow (in Russian).

Voronin, A. D. (1986). Osnovy fiziki pochv [Basics of soil physics]. Moscow University Press, Moscow (in Russian). 